\title{
ELECTROPHORETIC ANALYSIS OF PLASMA AND URINARY PROTEINS
}

\author{
By JOHN A. LUETSCHER, JR. \\ (From the Departments of Physical Chemistry and Medicine, Harvard Medical School, and \\ from the Medical Clinic of the Peter Bent Brigham Hospital, Boston)
}

(Received for publication October 20, 1939)

Accurate analysis of the protein fractions of human plasma has in the past been very difficult and time-consuming. Fractional precipitation by neutral salt, as in Howe's method (1), has proved useful because of its simplicity and because the most important pathologic variations in plasma proteins involve a gross diminution in the albumin fraction. Such methods have definite limitations : Butler's careful study (2) of curves describing the "salting-out" of human and horse serum demonstrated that the precipitation ranges of the globulin fractions overlapped one another grossly and that even the albumin-globulin separation was by no means sharp. That the "albumin" fraction after a single precipitation with neutral salt is grossly contaminated by globulin becomes most obvious when sera from nephrotic patients are studied. On dialysis of this "albumin" fraction against running distilled water a large amount of the protein separates as a water-insoluble precipitate.

The simple "salting-out" methods are thus very inaccurate in the cases in which they are of most interest. Combinations of dialysis, isoelectric precipitation and neutral salt precipitation, carefully worked out and frequently repeated, will allow the isolation of pure fractions, but such methods are not at present satisfactory as analytical procedures.

Tiselius (3) has developed an apparatus for the study of the migration of protein in the electric field, eliminating most of the difficulties previously encountered in such studies, and permitting a quantitative estimation of proteins as they separate during electrophoresis by means of a Toepler Schlieren method (4). With this apparatus he has studied, among other things, the proteins of horse serum $(5,6)$. The simplicity of the method, the sharp separation of the fractions, and the small amounts of material required combine to make it an excellent procedure for the study of human proteins.
Stenhagen (7) first pointed out that the principal electrophoretic fractions of normal human serum corresponded with those noted by Tiselius for horse serum, namely, albumin and $\alpha, \beta$, and $\gamma$ globulins, migrating with varying speeds in the electric field. Later Blix (8) studied normal human serum globulins and those of patients with pneumonia, and showed that the so-called $\alpha$ and $\beta$ fractions were usually increased during the acute phase of the disease. Recently, MacInnes and Longsworth (9), and Longsworth, Shedlovsky, and MacInnes (10) have reported their observations on serum and urinary proteins in a number of diseases. They have noted that the urinary protein pattern in nephrosis resembles normal serum, in spite of great variations in the serum albumin and globulins. In a number of febrile conditions they observed elevation of $\alpha$ globulin, and in myeloma, nephrosis and obstructive jaundice large increases of the $\beta$-globulin fraction, associated in the latter two diseases with an increase in blood lipids. In the present study of the proteins of normal and pathological plasmas and urines, the globulins have been analyzed into four fractions by electrophoresis at neutral reactions, and the albumins into two fractions at acid reactions.

\section{METHODS}

The principles involved in the Tiselius apparatus are simple. The plasma is layered in the lower half of a U-tube below buffer solution (against which the plasma has previously been dialyzed). Electrodes are placed in the buffer and direct current applied. The voltage and current are adjusted so as not to produce appreciable warming of the solution and consequent convection currents. This disturbance is minimized by running the apparatus in a bath at $1^{\circ} \mathrm{C}$., a temperature just below the point of maximum density of the solutions used. Under the influence of the electric field the protein ions move toward the anode if their charge is negative and toward the cathode if their charge is positive. The speed of migration is largely dependent on the charge of the protein ion under conditions of constant $\mathrm{pH}$ and salt concentration. The various fractions, combined with different 
amounts of base or acid at a given $\mathrm{pH}$ and salt concentration, migrate at different rates and gradually separate one from another, the original protein-buffer boundary breaking up into a number of boundaries representing fractions moving at various speeds.

The optical system utilizes the fact that at each " boundary," where there is a change of protein concentration, there is a corresponding change of refractive index. This change produces a downward deflection of the beam of light passing through the boundary, and the deflection can be measured by the movable Schlieren diaphragm. The degree of deflection at this point is proportional to the gradient of protein concentration; in other words, to $\mathrm{dC} / \mathrm{dS}$, where $\mathrm{C}$ is protein concentration and $\mathrm{S}$ is distance along the U-tube. Now, if deflection is plotted against position along the U-tube, a peak of deflection appears at each boundary, deflection being slight between boundaries. The area under each peak, $\int \frac{\mathrm{dC}}{\mathrm{dS}} \mathrm{dS}$, is proportional to the total change of protein concentration at that boundary and hence to the concentration of the fraction which that boundary represents. Automatic cameras for recording such diagrams have been developed by Philpot (11), Svensson (12), and Longsworth (13).

It is possible to study plasma under various conditions of $\mathrm{pH}$ and salt concentration as well as at any dilution. In order to retain satisfactory amounts of fractions of low relative concentration in plasma and urine, it was found necessary to use only slightly diluted plasma. In these studies normal plasma was diluted with not more than 50 per cent of its volume of buffer before dialysis, and plasma with lower protein concentration was dialyzed directly against buffer without previous dilution. In order to minimize boundary disturbances at these high protein concentrations, an ionic strength of 0.20 in phosphate buffers $(14,15)$ was employed. The $\mathrm{pH}$ was maintained at 7.8. One well-known disturbance during electrophoresis is produced by concentration gradients of buffer and leads to the so-called $\delta$-boundary (16). This effect was minimized as a source of confusion by the use of high ionic strength. Although increasing salt concentration diminishes the mobility (17) of most proteins, it causes a relative increase in migration rate of the $\boldsymbol{\gamma}$ fraction; and under the conditions used the $\boldsymbol{\gamma}$-boundary is largely separated from the $\delta$-effect. Under these conditions, electrophoresis which was essentially free from disturbance could be attained as well as a satisfactory rate of migration.

Within the range of plasma dilution employed no shift in relative concentration of any of the fractions was observed; this corresponds with the observations of McFarlane with the ultracentrifuge (18).

No correction has been made for differences of specific refractive increment between the various fractions, since we have no data on human serum protein components and since the studies by Adair (19) show only differences less than the error of our method in horse and sheep serum albumin and globulin.

\section{RESULTS}

\section{A. Electrophoresis of plasma at $p H 7.8$}

1. Normals. The same general fractions noted by Tiselius (5) in horse and Stenhagen (7) in human serum appear in our analyses. The large initial peak (Figure 1) represents the albumin;

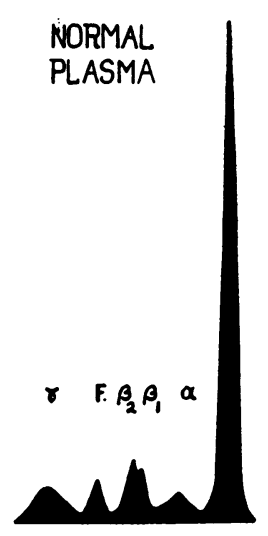
NEPHROTIC PLASMA
Mild Edema

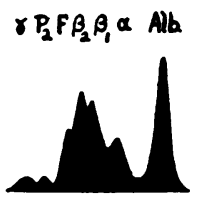

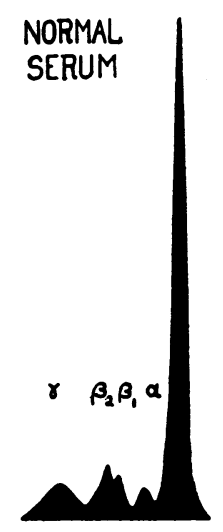

URINE

$\gamma \beta$ a Alb.

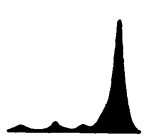

NORMAL ALBUMIN $\mathrm{pH} 4.0$

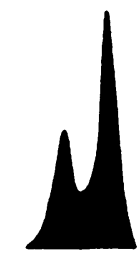

ALBUMIN $\mathrm{pH} 4.0$
Fig. 1. Schlieren Diagrams Representing the Distribution of Protein Fractions in Normal Plasma and Serum and in Nephrotic Plasma and Urine

The concentration of each fraction is proportional to the area under the peak representing that fraction. Alb. indicates albumin, and $\mathrm{F}$ fibrinogen. Electrophoresis was carried out at $\mathrm{pH} 7.8$ and ionic strength 0.2 unless otherwise indicated. The separation of albumins at $\mathrm{pH} 4.0$ is also illustrated. It will be noted that the usual large albumin peak is much reduced in nephrotic plasma, and at $\mathrm{pH} 4.0$; this is seen to be largely due to a diminution of one of the albumin components.

the subsequent peaks, in order, are: $\alpha$-globulin, the double-peaked $\beta$-fraction, fibrinogen, and the $\gamma$-globulin fraction.

The identification of the globulins constituting these fractions is best accomplished by the addition of known fractions to a serum or urine of known constitution and by observing which fraction is increased in amount. It seemed at first that direct measurement of mobilities of known fractions and comparison with the mobilities of 
fractions observed in serum could be used as a method of identification. On further study, however, two serious difficulties became apparent. The mobility of a protein is not entirely independent of its concentration, increasing concentration causing a very definite increase in mobility under certain conditions. ${ }^{1}$ Secondly, the mobility of a given protein in serum is very considerably affected by the presence and relative concentrations of the other constituents. However, we have never observed any change in the order of migration of the plasma proteins; an increase in concentration of a slower constituent may make it approach the next faster constituent, but not'pass it.

Fibrinogen is easily identified by its disappearance after clotting.

The true globulins can be separated by preliminary dialysis. On dialyzing serum against running distilled water an amorphous white precipitate appears. On electrodialysis, followed by acidification to about $\mathrm{pH} 5.5$, a blue-green jellylike precipitate results. Green's (20) study of the globulins of horse serum was partly followed. The white precipitate furnished most of the $\mathrm{pH} 6$ isoelectric precipitate, and the blue-green jelly most of the $\mathrm{pH} 5$ precipitate. The $\mathrm{pH} 5$ precipitate was a mixture, but the true globulin portion could be separated by "salting-out." On electrophoretic study, the $\mathrm{pH} 5$ precipitable globulin moved with the $\beta$-globulin, probably as $\beta_{2}$. The $\mathrm{pH} 6$ precipitable globulin showed two components, one moving with the $\beta$-globulin, probably as $\beta_{1}$; and the other presenting a boundary not seen in normal human serum, but appearing in several pathological sera, between the $\gamma$-globulin and the fibrinogen. The presence in normal serum of a component of such a low concentration was not detected because of overlapping by the broad $\gamma$-boundary. In mobility and isoelectric region it appears to correspond to Green's $P_{2}$.

The pseudoglobulin largely precipitable by 33 per cent saturation with ammonium sulfate is

1 Protein concentration influences the apparent mobility in two ways. At high concentration disturbances occur at the boundaries and, under these circumstances, the mobility of the advancing and retreating boundaries is markedly different. In addition there would appear to be an effect due to protein interactions. This effect is being extensively investigated in this laboratory by the electrophoretic and other methods. represented by the $\gamma$-boundary, and pseudoglobulin precipitable from 40 to 50 per cent saturation with ammonium sulfate moves in the $\alpha$-boundary.

The relative and absolute concentrations of the fractions of normal plasma are quite constant. The average figures obtained for normal human plasma are given in Tables I and II. ${ }^{2}$

\section{TABLE I}

Composition of normal and certain pathological plasmas (In grams of protein per $100 \mathrm{cc}$.)

\begin{tabular}{|c|c|c|c|c|c|c|c|c|}
\hline & \multirow{2}{*}{$\begin{array}{l}\text { Total } \\
\text { pro- } \\
\text { tein }\end{array}$} & \multirow{2}{*}{$\underset{\text { min }}{\text { Albu- }}$} & \multicolumn{5}{|c|}{ Globulins } & \multirow{2}{*}{$\begin{array}{c}\text { Fibrin- } \\
\text { ogen }\end{array}$} \\
\hline & & & $\alpha$ & $\beta_{1}$ & $\beta$ & $\beta_{\text {totsl }}$ & $\boldsymbol{\gamma}$ & \\
\hline \multicolumn{9}{|c|}{ NORMAL PLASMA } \\
\hline Average & 6.5 & 4.06 & 0.46 & 0.31 & 0.55 & 0.86 & 0.75 & 0.37 \\
\hline \multicolumn{9}{|c|}{ NEPHROTIC PLASMA } \\
\hline $\begin{array}{l}\text { Case I } \\
\text { Case II } \\
\text { Case IIIa } \\
\text { Case IIIb } \\
\text { Case IV }\end{array}$ & $\begin{array}{l}4.0 \\
4.9 \\
3.7 \\
4.2 \\
3.9\end{array}$ & $\begin{array}{l}1.10 \\
0.91 \\
0.37 \\
0.72 \\
0.34\end{array}$ & $\begin{array}{l}0.61 \\
1.36 \\
1.47 \\
1.33 \\
1.16\end{array}$ & \begin{tabular}{|l|}
0.62 \\
0.31 \\
0.16
\end{tabular} & $\begin{array}{l}0.74 \\
1.50 \\
0.92\end{array}$ & $\begin{array}{l}1.36 \\
1.81 \\
1.08 \\
1.38 \\
1.62\end{array}$ & $\begin{array}{l}0.19 * \\
0.25 \\
0.28 \\
0.24 \\
0.27\end{array}$ & $\begin{array}{l}0.74 \\
0.59 \\
0.50 \\
0.53 \\
0.51\end{array}$ \\
\hline
\end{tabular}

TERMINAL NEPHRITIC PLASMA

\begin{tabular}{l|l|l|l|l|l|l|l|l}
\hline Case V & 6.0 & 3.11 & 0.33 & 0.40 & 0.92 & 1.32 & 0.85 & 0.39 \\
Case VI & 5.3 & 3.17 & 0.30 & 0.51 & 0.55 & 1.06 & 0.45 & 0.32 \\
Case VII & 6.6 & 4.28 & 0.36 & 0.31 & 0.71 & 1.02 & 0.60 & 0.34 \\
\hline
\end{tabular}

AMYLOID DISEASE SERUM

\begin{tabular}{l|c|c|c|c|c|c|c|c}
\hline Case VIII & 5.0 & 1.31 & 0.83 & 0.51 & 0.94 & 1.45 & 1.41 & \\
\hline \multicolumn{7}{c}{ ACUTE RHEUMATIC FEVER PLASMA } \\
\hline Case IX & 5.4 & 1.68 & 0.56 & 0.54 & 0.36 & 0.90 & $1.81 *$ & 0.45 \\
Case X & 6.2 & 3.02 & 0.48 & 0.84 & 0.33 & 1.17 & 1.10 & 0.43 \\
\hline \multicolumn{7}{c}{ CIRRHOTIC PLASMA } \\
\hline Case XI & 6.7 & 3.15 & 0.54 & 0.49 & 0.74 & 1.23 & 1.26 & 0.52 \\
Case XII & 5.7 & 2.24 & 0.33 & 0.27 & 0.54 & 0.81 & 1.82 & 0.50 \\
\hline
\end{tabular}

* The $\gamma$-fractions in these two cases include the $P_{2}$ fraction. In Case $I P_{2}$ represented 0.08 gram, in Case IX, 0.40 gram.

2 As this paper was being prepared for publication, the important contribution of Longsworth, Shedlovsky and MacInnes (10) appeared, permitting a comparison of results thus far reported on relative composition of normal human serum proteins. The ratio of concentration of each globulin to the concentration of albumin is used, avoiding both the factor of dilution and artificial differences between plasma and serum.

(Continued on page 316) 
TABLE II

Percentage composition of proteins of normal and certain pathological fluids

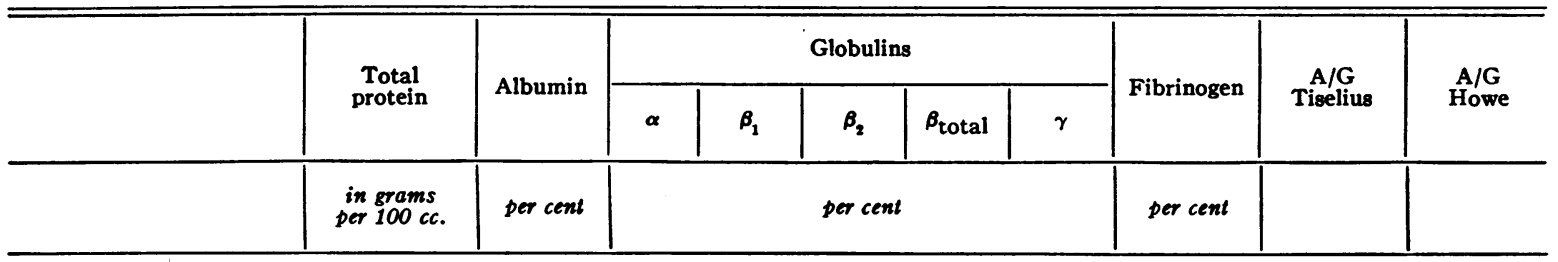

NORMAL PLASMA

\begin{tabular}{|c|c|c|c|c|c|c|c|c|c|c|}
\hline Average & 6.5 & 62.5 & 7.0 & 4.8 & 8.4 & 13.2 & 11.6 & 5.7 & $63 / 37$ & $62 / 38$ \\
\hline \multicolumn{11}{|c|}{ NEPHROTIC SYNDROME } \\
\hline $\begin{array}{l}\text { Plasma I } \\
\text { Urine I }\end{array}$ & $\begin{array}{l}4.0 \\
1.0\end{array}$ & $\begin{array}{l}27.4 \\
92.0\end{array}$ & $\begin{array}{r}15.2 \\
1.7\end{array}$ & 15.8 & 18.4 & $\begin{array}{r}34.2 \\
5.3\end{array}$ & $\begin{array}{l}4.8^{*} \\
1.0\end{array}$ & 18.4 & $\begin{array}{l}27 / 73 \\
92 / 8\end{array}$ & $43 / 57$ \\
\hline $\begin{array}{l}\text { Plasma III } \\
\text { Urine III }\end{array}$ & $\begin{array}{l}4.2 \\
0.6\end{array}$ & $\begin{array}{l}17.2 \\
83.3\end{array}$ & $\begin{array}{r}31.7 \\
4.5\end{array}$ & & & $\begin{array}{l}33.0 \\
10.4\end{array}$ & $\begin{array}{l}5.6 \\
1.8\end{array}$ & 12.5 & $\begin{array}{l}17 / 83 \\
83 / 17\end{array}$ & $26 / 74$ \\
\hline $\begin{array}{l}\text { Plasma IV } \\
\text { Urine IV }\end{array}$ & $\begin{array}{l}3.9 \\
0.4\end{array}$ & $\begin{array}{r}8.7 \\
67.7\end{array}$ & $\begin{array}{r}29.7 \\
5.9\end{array}$ & & & $\begin{array}{r}41.6 \\
\cdot 15.2\end{array}$ & $\begin{array}{r}6.8 \\
11.2\end{array}$ & 13.2 & $\begin{array}{r}9 / 91 \\
68 / 32\end{array}$ & $23 / 77$ \\
\hline \multicolumn{11}{|c|}{ TERMINAL NEPHRITIS } \\
\hline $\begin{array}{l}\text { Plasma V } \\
\text { Urine V }\end{array}$ & $\begin{array}{l}6.0 \\
0.2\end{array}$ & $\begin{array}{l}51.8 \\
68.7\end{array}$ & $\begin{array}{l}5.5 \\
3.4\end{array}$ & 6.7 & 15.3 & $\begin{array}{l}22.0 \\
14.7\end{array}$ & $\begin{array}{l}14.2 \\
13.2\end{array}$ & 6.5 & $\begin{array}{l}52 / 48 \\
69 / 31\end{array}$ & $62 / 38$ \\
\hline $\begin{array}{l}\text { Plasma VII } \\
\text { Urine VII }\end{array}$ & $\begin{array}{l}6.6 \\
0.15\end{array}$ & $\begin{array}{l}64.9 \\
80.5\end{array}$ & $\begin{array}{l}5.4 \\
3.1\end{array}$ & 4.7 & 10.8 & $\begin{array}{r}15.5 \\
8.3\end{array}$ & $\begin{array}{l}9.0 \\
8.1\end{array}$ & 5.2 & $\begin{array}{l}65 / 35 \\
81 / 19\end{array}$ & $68 / 32$ \\
\hline \multicolumn{11}{|c|}{ AMYLOID DISEASE } \\
\hline $\begin{array}{l}\text { Serum VIII } \\
\text { Urine VIII }\end{array}$ & $\begin{array}{l}5.0 \\
0.4\end{array}$ & $\begin{array}{l}26.2 \\
72.7\end{array}$ & $\begin{array}{r}16.7 \\
1.5\end{array}$ & 10.2 & 18.7 & $\begin{array}{r}28.9 \\
5.2\end{array}$ & $\begin{array}{l}28.2 \\
20.6\end{array}$ & & $\begin{array}{l}26 / 74 \\
73 / 27\end{array}$ & $42 / 58$ \\
\hline \multicolumn{11}{|c|}{ ACUTE RHEUMATIC FEVER } \\
\hline $\begin{array}{l}\text { Plasma IX } \\
\text { Urine IX }\end{array}$ & $\begin{array}{l}5.4 \\
0.05\end{array}$ & $\begin{array}{l}31.1 \\
40.0\end{array}$ & $\begin{array}{r}10.4 \\
6.0\end{array}$ & 10.0 & 6.7 & $\begin{array}{l}16.7 \\
24.0\end{array}$ & $\begin{array}{l}33.5^{*} \\
30.0\end{array}$ & 8.3 & $\begin{array}{l}31 / 69 \\
40 / 60\end{array}$ & $39 / 61$ \\
\hline \multicolumn{11}{|c|}{ CIRRHOSIS } \\
\hline $\begin{array}{l}\text { Plasma XII } \\
\text { Ascites XII }\end{array}$ & $\begin{array}{l}5.7 \\
0.6\end{array}$ & $\begin{array}{l}39.3 \\
41.1\end{array}$ & $\begin{array}{l}5.8 \\
4.5\end{array}$ & 4.8 & 9.4 & $\begin{array}{l}14.2 \\
13.8\end{array}$ & $\begin{array}{l}32.0 \\
34.5\end{array}$ & $\begin{array}{l}8.7 \\
6.1\end{array}$ & $\begin{array}{l}39 / 61 \\
41 / 59\end{array}$ & $44 / 56$ \\
\hline
\end{tabular}

* The $\gamma$-fractions in these two cases include $P_{2}$. In Case $I, P_{2}$ represented 2.1 per cent. In Case IX, it represented 7.4 per cent.

2. Nephrotic syndrome. The patients studied were three children and one adult presenting Svensson Longsworth Luetscher Kekwick
$\alpha /$ Albumin .. 0.13
0.12
0.11
0.08
B/Albumin .. 0.26
0.23
0.21
0.19
$\gamma /$ Albumin $\ldots 0.17$
0.20
0.19
0.43

The high $\gamma$ value observed by Kekwick (30) is due to the overlapping $\delta$-effect. The results of Blix are difficult to compare directly but appear to resemble those of Kekwick. The good agreement of these results is quite gratifying. gross proteinuria, hypoproteinemia, and edema, without significant change of renal function or blood pressure.

The most striking change is the great loss of albumin from the plasma, which is even more severe than indicated by the ratio of albumin to globulin ( $\mathrm{A} / \mathrm{G}$ ratio), as measured by Howe's method. Compensatory changes involve the increases of $\beta$ - and $\alpha$-globulins, $\beta$ increasing first, and $\alpha$ rising strikingly only when the albumin is 
almost totally lost. ${ }^{3}$ The $\gamma$-fraction, least active osmotically, is diminished. Fibrinogen is definitely increased, accounting at least in part for the high corpuscular sedimentation rates observed in nephrotic blood. In one case $\mathrm{P}_{2}$ appeared and was apparently related to increase of true globulin and diminution of $\gamma$.

The urines contain roughly the same fractions as normal serum; fibrinogen is not ordinarily seen, nor is $\mathrm{P}_{2}$. The $\beta$-boundary is single. This is perhaps explained by the fact that fibrinogen and the more insoluble globulins are precipitated from dilute solutions of $\mathrm{pH} 5.5$ to 6.5. It is known that urinary "casts" are soluble in alkaline solutions.

When there is over 1 gram per cent of albumin in the plasma, the urinary protein is about 90 per cent albumin. When the albumin in the plasma falls to very low levels, the urinary albumin becomes lower and the urinary globulin relatively more important, approaching a ratio similar to that of normal serum, as has been pointed out by MacInnes and Longsworth (9).

3. Terminal glomerulonephritis. The three cases studied were all in a state of uremia. One gave a history of acute glomerulonephritis, with persistent activity; one had an insidious onset, with an interlude of mild edema; one had gone through an acute attack, a nephrotic stage, and a latent period of 10 years.

Analyses of the three plasmas approximated the normal. There was a slight diminution of the albumin in two cases, and the $\beta$-globulin was somewhat higher than usual in all cases.

Urines contained lower concentrations of protein than the nephrotics, but much the same proportion of constituents. Here again, diminution of plasma albumin concentration is reflected in a lower proportion of albumin in the urine.

4. Amyloid disease. Only one patient was studied. Chronic tuberculosis of the lymphatic system preceded the development of amyloidosis in this case. During life the patient presented a classical picture of amyloid disease and the diagnosis was confirmed by necropsy findings.

The albumin was much reduced in plasma, but unlike a nephrotic serum with a similar diminu-

\footnotetext{
3 Longsworth and MacInnes in a recent paper (31) relate this increase in $\boldsymbol{\beta}$-globulin to lipoids.
}

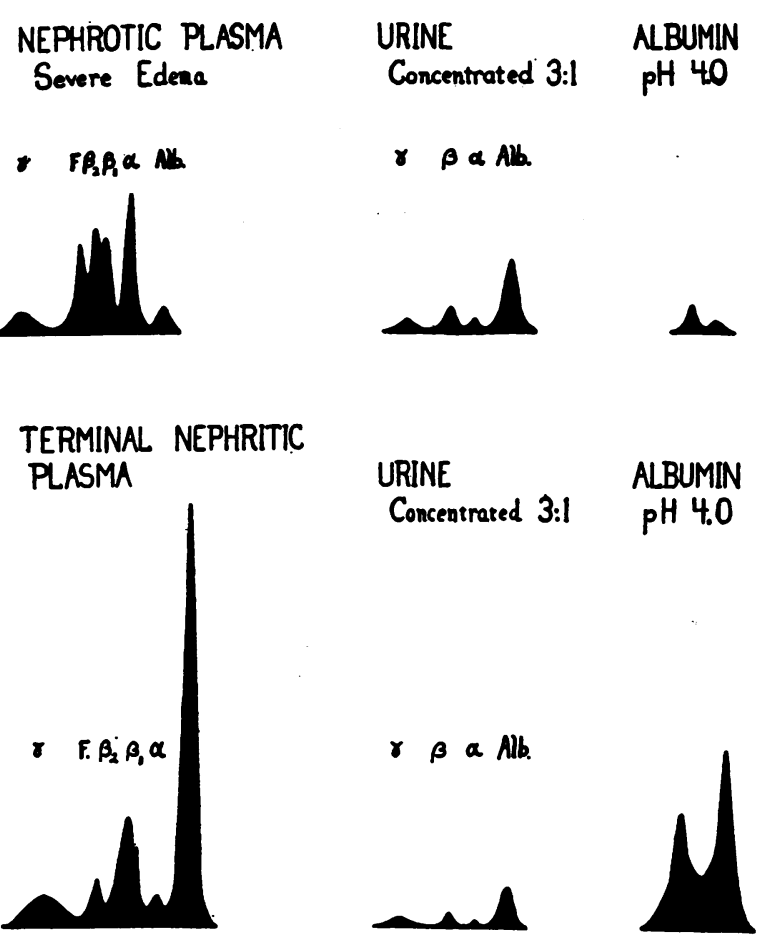

Fig. 2. Schlieren Diagrams Representing the Distribution of Protein fractions in the Plasma and Urine of Patients with Glomerulonephritis in the Nephrotic and Terminal Stages

A very severe reduction of albumin characterizes the nephrotic plasma shown above. Corresponding to this situation, the urine contains less albumin and more globulin than seen in the milder case. The ratio of albumin components is reversed in both blood and urine. The plasma of terminal glomerulonephritis is more nearly normal, but shows mild changes of the same type seen in the nephrotic stage.

tion of albumin, the globulin increase was most striking in the $\gamma$-fraction. The urine reflected this anomaly with a corresponding increase in the $\gamma$-fraction, otherwise resembling the other urines studied.

5. Rheumatic heart disease with failure. Several patients in the active phase of rheumatic fever, and one patient without obvious signs of activity, were studied. In a young girl with rheumatic pancarditis, there was a great elevation of the $\gamma$-fraction. There was also the appearance of $\mathrm{P}_{2}$ and an increase in $\beta_{1}$ (both globulins). Fibrinogen was relatively and absolutely increased. The albumin was considerably decreased. A woman with rheumatic pericarditis showed very similar changes, but somewhat less striking. 
The urines from these two cases showed relatively less albumin and more globulin than any other urines thus far studied. The proportions of the various globulins in urine resembled those in blood.

In an old case of rheumatic heart disease without obvious activity a similar type of change in plasma proteins was evident; unfortunately, the urinary output of protein in this case was too low to study.

6. Cirrhosis of the liver. A diminution of albumin and an increase in the $\gamma$-globulin fraction appear to be the principal changes in cirrhosis. In the absence of ascites, the same changes are evident, but not so striking as when ascites has developed (Figure 3 ). The ascitic fluid of a

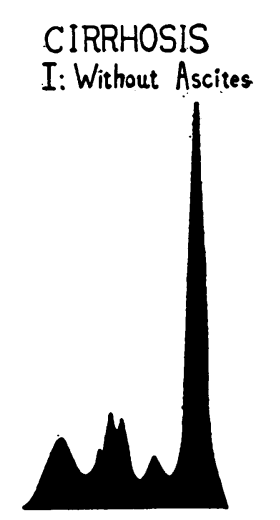

AC. RHEUMATIC FEVER PLASMA

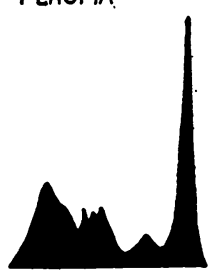

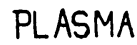

$$
\text { II: With Ascites }
$$

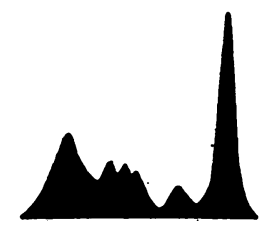

AMYLOID DISEASE SERUM

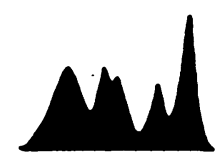

ALBUMIN
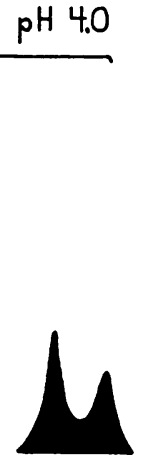

URINE Conc. 3:1

Fig. 3. Schlieren Diagrams Representing the Distribution of Protein Fractions in the Plasma of Laennec's Cirrhosis and Acute Rheumatic Fever and in the Serum and Urine of Amyloid Disease

Plasma proteins in two cases of cirrhosis, with reduction of albumin and increase of globulin, especially the $\gamma$-fraction, show deviations from normal in two stages of the disease. In the more abnormal plasma, the ratio of albumin components was reversed. An extreme example of the globulin increase of acute rheumatic fever is illustrated. The plasma and urine of amyloid disease resemble those of nephrosis except in the $\gamma$-fraction, which is high in amyloid disease, low in nephrosis. cirrhotic patient showed nearly the same relative composition as the plasma, though the total protein concentration of the fluid was only one-tenth that of plasma.

\section{B. Separation of two albumin components at pH 4.0}

In any study of serum albumin, it is necessary to distinguish between a purified albumin preparation and the crude "albumin fractions" which in pathological cases may contain more globulin than albumin. Previous studies of albumin fractions from nephrotic sera have demonstrated the importance of this distinction. Alving and Mirsky (21) studied nephrotic serum "albumin" fractions, and found them quite abnormal in cystine content; but when they dialyzed out the globulin and studied the resulting albumin, the cystine content was very close to that of normal albumin. Hewitt (22), who has studied serum proteins extensively, Cavett and Gibson (23), and Widdowson (24) had previously found no difference in physical measurements of normal and nephrotic serum albumin. Friend, Ferry, and Oncley (25), studying nephrotic urinary albumin, found it to have a very high dielectric constant increment. ${ }^{4}$

At neutral reactions, serum albumin migrates electrophoretically as a single individual, and there is no apparent difference between the normal serum albumin and that of pathological serum or urine.

J. D. Ferry (26) observed crystallization of a fraction of the albumin of horse serum when the albumin was concentrated in the presence of sufficient sulfuric acid to bring the $\mathrm{pH}$ to 4.0 and when the temperature was approximately $25^{\circ} \mathrm{C}$. McMeekin (27) has confirmed this observation and separated horse serum albumin into two fractions of different properties by crystallization as sulfate from concentrated, salt-free solutions at $\mathrm{pH}$ 4.0. In McMeekin's work, the starting material was highly purified albumin, completely free of carbohydrate. Following these experiments, we have shown (28) that carbohydrate-free albumin is separable into two components by electrophoresis at $\mathrm{pH} 4.0$, and that a similar separation is possible in human serum and urinary albumins. The albumins studied migrated as one

\footnotetext{
${ }^{4}$ Nephrotic urine in which the proteins are poor in sulfur has been reported (32).
} 
individual at neutral reactions both before and after study at $\mathrm{pH}$ 4.0. The results are independent of time, and $\mathrm{pH}$ is within the stability range of serum albumin as determined by Svedberg and Sjögren (29).

Normal human serum albumin at $\mathrm{pH} 4.0$ shows about 67 per cent of a faster-moving component, " $\alpha$," and about 33 per cent of a slower-moving component, " $\beta$ " (Figure 1). In the nephrotic, both serum and urinary albumins show a reversal of the ration of $\alpha / \beta$ albumins, the degree of reversal varying more or less with the loss of albumin (Figures 1,2). There is no significant difference between the ratio of $\alpha / \beta$ albumins in blood and urine.

In cirrhosis of the liver with diminution of serum albumin, a reversal also takes place. Here $\beta$ albumin is only slightly affected, while $\alpha$ albumin is considerably diminished.

In terminal nephritis, the ratio is nearly normal, but in a case where the albumin is lowered there is some loss of the " $\alpha$ " component. Again, the ratios in blood and urine do not differ significantly.

\section{DISCUSSION}

The reversed ratio of the two albumin components in nephrosis is significant. Since the ratio of the components is practically the same in blood and urine, it is impossible to explain the reversal on the same ground as in the case of the ratio of albumin to globulin ( $A / G)$, where there is loss of large amounts of albumin and little loss of globulin. It must be assumed that there is an abnormal mechanism of production, either due to excessive activity in the face of great albumin losses, or due to some damage at the site of production. It is interesting that in hepatic cirrhosis, with other evidence of liver damage, the ratio of the two albumin components is also reversed.

It is possible to compare plasma and urine concentrations of the various fractions and to correlate these with concepts of pathological changes. In the nephrotic syndrome, the relative concentration of albumin in urine greatly exceeds its relative concentration in blood. Reduced to less than 10 per cent of the plasma proteins, albumin still represents 70 per cent of the protein in urine. When the plasma albumin concentration is 1 gram per 100 cc., albumin constitutes 90 per cent of the urinary protein. Amyloid disease presents a similar picture, though less striking.
The kidney of terminal glomerulonephritis, on the other hand, with practically normal plasma proteins excretes a urine with considerably less protein than in nephrosis. Even in the presence of a practically normal plasma albumin to globulin ratio the urine contains hardly as much albumin as appears in nephrotic urine when the plasma albumin is reduced to one-tenth of normal.

If it is assumed that urinary protein escapes through the glomerulus, the findings for terminal nephritis could be interpreted as the loss from a few glomeruli, with the albumin lost only slightly more readily than globulin. The findings from nephrotic urine, on the other hand, suggest many more glomeruli involved, with albumin lost many times more readily than globulin.

From a technical standpoint, the Tiselius method allows an evaluation of the albumin to globulin ratio $(A / G)$ as estimated by precipitation with sodium sulfate. The $A / G$ ratio is reasonably accurate so long as the albumin is not greatly reduced and so long as globulin increase does not involve the fractions which seriously contaminate the "albumin fraction." In plasma containing more than 1.5 grams per cent of albumin, and with globulin increase confined to the $\gamma$-fraction, the error in albumin estimation is less than 30 per cent. The error of the "salting-out" method is very high in plasma with albumin concentration below 1.5 grams per cent or with increase in the $\beta$-globulin. The points, unfortunately, do not fall on a curve sufficiently well to make a correction factor possible. A change in the technique of the "salting-out" method would be a better approach, and work on this is in progress.

The analyses of blood and urine at $\mathrm{pH} 7.8$ show changes characteristic of each disease studied. Pathological conditions in which protein disturbances were to be expected were chosen for this first study. The work will be extended, and, it is hoped, will prove to be of some diagnostic value.

\section{SUMMARY}

1. Plasma and urinary proteins have been analyzed in the Tiselius electrophoresis apparatus. In normal individuals and in patients suffering from a number of diseases, plasma protein distributions of characteristic types have been noted.

2. Analysis of serum albumin has shown two components at $\mathrm{pH}$ 4.0. A reversal of the normal 
ratio of these components has been noted in the nephrotic syndrome and in advanced cirrhosis of the liver.

3. The ratio of nephrotic albumin components being the same in plasma and urine suggests a change in the formation of albumin.

4. Results obtained with the salting-out and the electrophoretic methods of protein fractionation have been compared.

I am deeply indebted to Dr. Edwin J. Cohn and Dr. Arne Tiselius for their kind suggestions and criticisms of this work; to Dr. Henry A. Christian and Dr. Soma Weiss for their advice and suggestions; and to Dr. Allan M. Butler, Dr. J. P. O'Hare, and Dr. Robert T. Monroe for their helpfulness in obtaining clinical material.

\section{BIBLIOGRAPHY}

1. Howe, P. E., The use of sodium sulfate as the globulin precipitant in the determination of proteins in blood. J. Biol. Chem., 1921, 49, 93.

2.(a) Butler, A. M., and Montgomery, H., Solubility of the plasma proteins. I. Dependence on salt and plasma concentrations. J. Biol. Chem., 1932, 99, 173.

(b) Butler, A. M., Blatt, H., and Southgate, H., Ibid. II. Dependence on $\mathrm{pH}$, temperature, and lipid content in concentrated solutions of potassium phosphate and application to their separate precipitation. J. Biol. Chem., 1935, 109, 755.

3. Tiselius, A., Moving boundary method of studying the electrophoresis of proteins. Thesis, Almqvist and Wiksells Upsala, 1930. Nova Acta Soc. Sci. Upsal., 4, 7.

4. Schardin, H., Das Toeplersche Schlierenverfahren. Forschungsheft, 367, VDI-Verlag, Berlin, 1934.

5. Tiselius, A., Electrophoresis of serum globulin. Biochem. J., 1937, 31, 313.

6. Tiselius, A., Ibid. II. Electrophoretic analysis of normal and immune sera. Biochem. J., 1937, 31, 1464.

7. Stenhagen, E., Electrophoresis of human blood plasma; electrophoretic properties of fibrinogen. Biochem. J., 1938, 32, 714.

8. Blix, G., Quantitative Bestimmung von electrophoretisch getrennten Serumglobulinen. Ztschr. f. d. gesamte exp. Med., 1939, 105, 595.

9. MacInnes, D. A., and Longsworth, L. G., Electrophoretic studies on blood sera. Science, 1939, 89, 438.

10. Longsworth, L. G., Shedlovsky, T., and MacInnes, D. A., Electrophoretic patterns of normal and pathological human blood serum and plasma. J. Exper. Med., 1939, 70, 399.

11. Philpot, J., Direct photography of ultracentrifuge sedimentation curves. Nature, 1938, 141, 283.

12. Svensson, H., Direkte photographische Aufnahme von Elektrophorese-Diagrammen. Kolloid Ztschr., 1939, 87, 181.

13. Longsworth, L. G., A modification of the Schlieren method for use in electrophoretic analysis. J. Am. Chem. Soc., 1939, 61, 529.

14. Cohn, E. J., Activity coefficients of ions in certain phosphate solutions; a contribution to the theory of buffer action. J. Am. Chem. Soc., 1927, 49, 173.

15. Green, A. A., Preparation of acetate and phosphate buffer solutions of known $\mathrm{pH}$ and ionic strength. J. Am. Chem. Soc., 1933, 55, 2331.

16. Longsworth, L. G., and MacInnes, D. A., Electrophoresis of proteins by the Tiselius method. Chem. Rev., 1939, 24, 271.

17. Davis, B. D., and Cohn, E. J., Influence of ionic strength and $\mathrm{pH}$ on electrophoretic mobility. J. Am. Chem. Soc., 1939, 61, 2092.

18. McFarlane, A. S., An ultracentrifugal investigation of the serum proteins. Biochem. J., 1935, 29, 407.

19. Adair, G. S., and Robinson, M. E., The specific refractive increments of serum-albumin and serumglobulin. Biochem. J., 1930, 24, 993.

20. Green, A. A., Amphoteric properties of certain globulin fractions of normal horse serum. J. Am. Chem. Soc., 1938, 60, 1108.

21. Alving, A. S., and Mirsky, A. E., The nature of plasma and urinary proteins in nephrosis. J. Clin. Invest., 1936, 15, 215.

22. Hewitt, L. F., Identity of urinary albumin. Biochem. J., 1927, 21, 1109.

23. Cavett, J. W., and Gibson, R. B., Comparison of racemization curves for urinary edema fluid, and blood plasma proteins. J. Clin. Invest., 1931, 10, 857.

24. Widdowson, E. M., A comparative investigation of urine- and serum-proteins in nephritis. Biochem. J., 1933, 27, 1321.

25. Friend, D. G., Ferry, J. D., and Oncley, J. L., Dispersion of dielectric constant of solutions of urinary proteins. J. Biol. Chem. (Proc.), 1938, 123, xxxix.

26. Ferry, J. D., Crystallization of a fraction of horse serum albumin from salt-free solutions. Reported before Division of Biological Chemistry, 96th meeting of the American Chemical Society, Milwaukee, September, 1938.

27. McMeekin, T. L., Preparation and properties of crystalline horse serum albumin of constant solubility. J. Am. Chem. Soc., 1939, 61, 2884.

28. Luetscher, J. A., Jr., Identification of more than one albumin in horse and human serum by electrophoretic mobility in acid solution. J. Am. Chem. Soc., 1939, 61, 2888.

29. Svedberg, T., and Sjögren, B., The pH stability range of serum albumin and serum globulin. J. Am. Chem. Soc., 1930, 52, 2855.

30. Kekwick, R. A., Electrophoretic analysis of normal human serum. Biochem. J., 1939, 33, 1122.

31. Longsworth, L. G., and MacInnes, D. A., An electrophoretic study of nephrotic sera and urine. J. Exper. Med., 1940, 71, 77.

32. Grabfield, G. P., and Prescott, B., Studies on nitrogen and sulfur metabolism in Bright's disease. VII. Sulfur content of urinary protein. Arch. Int. Med., 1936, 57, 1081. 